\title{
Ethno-pedagogical conditions for forming a healthy lifestyle in the educational process of younger schoolchildren \\ Condiciones etnopedagógicas para la formación de un estilo de vida saludable en el proceso educativo de los niños de escuela primaria \\ ${ }^{1}$ Marzhangul A. Kusainova, *Riza N. Zhapanova, *Galiyabanu M. Kertaeva, **Sayan T. Zhanbyrbaeva, **Laura E. Alipbayeva \\ * Buketov Karaganda State University (Republic of Kazakhstan), ** Karaganda Medical University (Republic of Kazakhstan)
}

\begin{abstract}
Insufficient attention is being paid to the potential of applying folk pedagogics and ethnopedagogics in improving society, which is a serious omission that reduces the effectiveness of the formation of a healthy lifestyle for younger students and does not contribute to the continuity of generations in this matter, including preservation of national values and culture. The purpose of the study is to investigate these issues, analyse the works of Kazakh and foreign scientists and formulate proposals for improving the educational process aimed at creating a healthy lifestyle for children in classroom and extracurricular activities. This article investigates the formation of a healthy lifestyle in primary school age. The author of the paper argues that this process should be based on the principles of folk pedagogy and ethno-pedagogy, since it is precisely under the current conditions of globalization and unification of cultures that they can ensure the continuity of generations in the Republic of Kazakhstan in preserving and enhancing national traditions and values of training and education. The author suggests creating a healthy lifestyle for children in classroom and extracurricular activities, attracting prominent Kazakh scientists, writers, poets, local historians, artists to the process, including setting up sightseeing walking tours around Kazakhstan, which will provide younger students with physical activity, necessary knowledge and will facilitate the development of healthy habits associated with maintaining a healthy lifestyle. The paper also draws attention to the fact that a personal example of teachers and parents is the best motivation for younger students in the formation of their healthy lifestyle.
\end{abstract}

Keywords: ethnopedagogics, public education, healthy lifestyle, primary school age, folk pedagogy.

Resumen. No se presta suficiente atención a las posibilidades de utilizar la pedagogía popular y la etnopedagogía para mejorar la sociedad, lo que constituye una omisión grave que reduce la efectividad de la formación de un estilo de vida saludable entre los niños de la escuela primaria y no contribuye a la continuidad de generaciones en esta materia, incluso la preservación de los valores y la cultura nacionales. El propósito de la investigación - es estudiar estos temas, analizar los trabajos de científicos kazajos y extranjeros y formular propuestas para mejorar el proceso educativo dirigido a la formación de un estilo de vida saludable para los niños en la escuela y las actividades extraescolares. Este artículo analiza las características de la formación de un estilo de vida saludable en la escuela primaria. El autor del artículo sustenta la tesis de que este proceso debe basarse en los principios de la pedagogía popular y la etnopedagogía, ya que en las condiciones modernas de globalización y unificación de culturas son capaces de asegurar la continuidad de generaciones en la República de Kazajstán en la preservación y mejora de las tradiciones nacionales y valores de formación y educación. El autor propone formar un estilo de vida saludable para los niños en las lecciones educativas y actividades extracurriculares, involucrando a destacados científicos, escritores, poetas, historiadores locales, artistas kazajos en el proceso, así como organizar excursiones a pie a los lugares de interés de Kazajstán, que proporcionarán a los niños de la escuela primaria la actividad física, los conocimientos necesarios y permitirán desarrollar buenos hábitos asociados con un estilo de vida saludable. El artículo también llama la atención sobre el hecho de que el ejemplo personal de los maestros y los padres es la mejor motivación para que los niños de la escuela primaria formen su estilo de vida saludable. Palabras clave: etnopedagogía, educación popular, estilo de vida saludable, niños de la escuela primaria, pedagogía popular.

\section{Introduction}

Younger school age is the most important stage in a person's life. It is the time when the child's personality is formed, values and national traditions are instilled, along with the desire to maintain and strengthen health. It is well known that about $40 \%$ of diseases of the body, including psychosomatic disorders, are formed in childhood. This indicates that the education system in the school should educate children in their desire to lead a healthy lifestyle and make the necessary time to address this matter in the course of educational process (Yarlykova and Koryagina, 2016; Yarlykova, 2015).

At the same time, insufficient attention is being paid to the potential of applying folk pedagogics and ethnopedagogics in improving society, which is a serious omission that reduces the effectiveness of the formation

Fecha recepción: 03-04-20. Fecha de aceptación: 25-07-20

Marzhangul A. Kusainova

kusainova5349@unesp.co.uk of a healthy lifestyle for younger students and does not contribute to the continuity of generations in this matter, including preservation of national values and culture. This study will investigate these issues, analyse the works of Kazakh and foreign scientists and formulate proposals for improving the educational process aimed at creating a healthy lifestyle for children in classroom and extracurricular activities (Smirnov, 2016).

The research methodology is defined by a combination of general (description, content analysis, comparative and system analysis, generalization) and special (historical, pedagogical, cultural, literary) methods. The complex of these methods within the framework of an interdisciplinary approach to the study of the issue allowed to fully elaborate the specifics of ethnopedagogical conditions for the formation of a healthy lifestyle for younger students in the Republic of Kazakhstan.

It should be noted that, in younger students, the formation of knowledge about a healthy lifestyle and the desire to follow it is largely based on national culture, character and values, since each society has its own ideas 
about how this should be done, what methods and means are better to be guided by, etc. In this regard, authors believe that the science of ethnopedagogics allows to consider the national and cultural features of teaching and raising children in the process of forming their knowledge and skills of a healthy lifestyle (Popova, 2016; Popova, 2017).

\section{Ethnopedagogics in the process of introducing children to a healthy lifestyle}

Ethnopedagogics is a science that explores folk pedagogics as a conventional practice of education (training and upbringing), historically developed among different ethnic groups. Ethnic revival is increasingly written by modern scholars from various fields of science. They point to the emerging tendency in the development of all mankind, which was most pronounced in the late $20^{\text {th }}-$ early $21^{\text {st }}$ centuries. In particular, the fundamental work on this topic was written in 1976 by the famous Tatar scientist Ya.I. Khanbikov. His book «From the History of Pedagogical Thought of the Tatars» (Khanbikov, 1976) was devoted to the educational role of ethnopedagogics in the educational process, in the moral, mental, physical, aesthetic, and conventional education of a person.

The concept of «ethnopedagogics» was developed and introduced into scientific use in 1974 by the Russian academician G.N. Volkov. He did not only present a detailed definition of the term, but also theoretically described ethnopedagogics as an independent field of pedagogics. The same scientist clarified and distinguished between the concepts of «ethnopedagogics " and «folk pedagogics». In his opinion, ethnopedagogics is the field of theoretical research, while folk pedagogy is the experience of public education, including relevant ideas, methods and tools. G.N. Volkov defined ethnopedagogics as the science of the empirical experience of ethnic groups in the education and upbringing of children, instilling aesthetic and moral-ethical views in them on the basis of primordial values of the family, clan, tribe, nationality, nation. He considered folk ethnopedagogics as an object of ethnopedagogics - a complex of knowledge and upbringing skills, which are represented in ethnocultural primordial traditions, folk art, special forms of communication and interaction between children and adults. In his research, G.N. Volkov (1974) drew attention to the fact that folk pedagogics combines the experience of upbringing and centuries-old everyday culture. In this regard, it can be stated that these concepts are interrelated and directly affect the educational process of the younger generation in a particular society.

G.N. Volkov identified the following main tasks of ethnopedagogics:

- determination of causal relationships and patterns of formation and development of the conventional pedagogical culture of peoples, factoring in the impact of a combination of economic, social, political and other factors on it;

- the establishment of ethnic characteristics of folk pedagogics within the framework of conventional cultures of various ethnic groups;

- study of the possibilities of applying advanced national pedagogical experience and heritage in the modern education system;

- possibilities of incorporating pedagogical approaches and methods of previous generations into modern educational practice (Volkov, 1974).

The works of the Czech humanist teacher Ya.A. Komenskiy (2009) were also essential for studying the problems of moral education of children within the framework of conventional folk culture. In his opinion, the family plays a special role in the moral education of children, therefore he concentrated mainly on the study of the family education system, which absorbed the principles of folk pedagogics. According to this researcher, the future of the people depends on the upbringing of the personality of the younger generation.

The founder of Russian pedagogical anthropology, an outstanding teacher K.D. Ushinsky drew attention to the fact that the national identity of the people is clearly expressed in its folklore. He analysed and characterized the peculiarities of the national upbringing of different nationalities and came to the conclusion that each nation has special signs of a national upbringing system. K.D. Ushinsky noted the special role of public pedagogy in the educational process and associated it with getting an education at school. In his opinion, folk pedagogy allows preserving the uniqueness of the people, it is it that develops a person's nationality, national character and national self-identification (Ushinsky, 1857). Famous Russian teacher G.S. Vinogradov in the book «Folk Pedagogics» (Vinogradov, 1997) described this phenomenon not only as a system, but as a combination of knowledge and skills. He believed that public pedagogy is a complex of skills, upbringing methods, which are aimed at shaping the personality of children in a certain direction. It should be noted that the accumulated experience of ethnopedagogics is used today to educate an ecooriented personality type by collecting and studying information about conventional culture within the framework of ecology. The result was a science called «ethnoecology», which in Western research literature is called «cultural anthropology» (Burger, 2002).

We shall draw attention to the fact that the formation of aspirations for a healthy lifestyle in younger schoolchildren relates to the issues of spiritual and moral education of children, which forms the basis of modern pedagogical science, because it is the younger generation that provides the future of the country. According to M.A. Petrenko, spirituality manifests itself, first of all, in the fact that a person can and wants to transgress their narrow interests in the name of expanding and deepening their consciousness, to realize the importance of interacting with another consciousness and to accept the world in all the diversity of its manifestations through the lens of their accumulated values. These values, in particular, include: responsibility, conscience, duty, love, compassion, beauty, mercy, wisdom (Petrenko, 2018).

In this regard, spirituality characterizes the highest level of development of personality consciousness. With 
that, the upbringing of a spiritually developed personality is, of course, closely connected with the cultural experience of a particular nation, its ideals and values, and its historical past. Many scholars involved in ethnopedagogy have investigated these issues. Ethnologists believe that ethnic culture is a system of beliefs, values, customs and traditions shared by most representatives of a particular society. In other words, ethnopedagogics explores the formed experience of ethnic groups in the education and upbringing of the younger generation, the development of moral and ethical views on the historical values of a particular nation. Ethnopedagogics is based on simple truths instilled in children in their families: courtesy, modesty, respect for elders, honesty, and morality. In modern society, they are especially in demand, since the process of globalization gradually leads to the disappearance of original cultures and ethnic groups as a result of unification. Ethnopedagogics in these conditions is especially relevant and important, because it allows to preserve, increase, and broadcast the cultural experience of peoples and to form their ethnic self-identification (Nigmatov, 2017).

In the Republic of Kazakhstan, much attention is paid to introducing younger students to a healthy lifestyle. The system of pedagogical and philosophical views of A. Kunanbaev (1977) and I. Altynsarin (1976) is largely based on the problems of improving the hygienic culture, strengthening health and shaping the need for a healthy lifestyle from early childhood. In particular, A. Kunanbaev in his work «Words of edification» points to the traditional Kazakh priority in the education of such qualities as moral purity of thoughts, industriousness, intelligence, the need for constant physical and moral self-improvement from childhood.

As noted above in this study, every nation strives for a healthy, bold and strong future offspring, in this regard, Kazakhs are no exception, therefore, in the Republic of Kazakhstan there are certain means and methods of pedagogics that contribute to the formation of the desire of primary schoolchildren to a healthy lifestyle. In particular, in folklore (fairy tales, epics, sayings, proverbs, songs), the ideal of a physically seasoned, manly, courageous, strong and brave hero, for example, Koblandy-batyr and Alpamys-batyr, is praised.

The formation of a healthy lifestyle in the educational process of younger schoolchildren, taking ethnopedagogics into account, has been studied by many Kazakh scientists, including Zh. Aymautov (1999) and A. Baitursynov (1995). In particular, J. Aymautov believes that the upbringing of a physically healthy child should factor in national cultural characteristics, ethical and aesthetic folk ideals, it should also proceed from the study of physiology, anatomy, hygiene, psychology, gymnastics, ethics, and logic. He draws attention to the fact that the body is a receptacle of the soul, which corresponds to the proverb «sound mind in a sound body» and indicates ways to increase the level of physical, intellectual, moral development through parenting teachers and children. The scientist is also convinced that younger schoolchildren should be associated with a healthy lifestyle, primarily in families and at schools, relying on folk pedagogy and Kazakh customs and traditions (Baitursynov, 1995).

According to A. Baitursynov, the mentor must feel the mood and «know the nature of the child». This implies an understanding at a deep level of the characteristics of the physical and mental development of primary schoolchildren, since it is at this age that knowledge of a healthy lifestyle is placed in the minds of children. It is important for teachers and parents to learn to distinguish between their inner states in order to correctly formulate in them the desire to observe personal hygiene rules, develop physical and mental abilities, and also follow the spiritual and moral ideals of society. According to this scientist, the younger student in the process of learning the basics of a healthy lifestyle should be aware that their health is the greatest wealth for them, which is important to preserve and improve, as evidenced by the entire experience of Kazakh folk culture (Baitursynov, 1995).

Of great scientific value are also the original works and contemporary works by Kh. Dosmukhamedov, who devoted many years of his life to research in the field of natural sciences, anatomy, medicine, biology, epidemiology, and human hygiene. In his work «Protecting the health of students», the scientist draws attention to the fact that it is at the primary school stage when students learn the fundamental principles of hygiene, prevention of diseases of the organs of vision and breathing, hearing, as well as sanitary and hygienic recommendations for a healthy lifestyle are provided. Kh. Dosmukhamedov pointed out that teaching aids should not be taken as a comprehensive and complete presentation of these issues, however, guided by the material in the manuals, children acquire the necessary personal hygiene skills and learn a lot of useful information about a healthy lifestyle (Dosmukhamedov, 1991). All of the above indicates the presence of a rich and valuable national experience in Kazakh science, which is very relevant at present and should be applied in the practical work of teachers in teaching younger students a healthy lifestyle.

\section{The problems of forming the day regimen in primary school children}

The basis of a healthy lifestyle for younger students is the rational regime of the day, work and rest, proper nutrition, physical activity and the absence of bad habits. In primary school age, observance of the day regimen is essential. Children aged 7-10 years old have an immature nervous system, therefore the threshold of nerve cell depletion is very low. At the same time, they are faced with the need to quickly adapt to complex mental and physical stresses for the child's body caused by breaking old behavioural stereotypes, systematic training, and the emergence of new increased requirements to different physiological systems. Proper combination and alternation of work and rest allows to optimize the functions of the child's body, better adapt to school with minimal costs. However, a violation of the day regimen can cause significant deviations in the health of the child, 
lead to neurosis and apathy (Yarlykova, 2015).

The day regimen includes a full sleep; walks, games, physical education and sports in the fresh air; learning activities at school and at home; nutrition; free time and rest; personal hygiene. The healthy lifestyle of primary schoolchildren is largely ensured by motor activity. Children should not experience a lack thereof, as it is their natural need (Agafonova and Agafonov, 2016). In this regard, the restriction of motor activity becomes the cause of hypokinesia, which causes serious health issues for students. At primary school age, the most important task for the body becomes mastery of all types of movements, testing and development of motor abilities in order to properly control the body and control their actions in the outer space. Optimal motor regimen implies not only maintaining the initial state of health, but also ensuring a certain frequency and systematic load. Classes conducted with younger students should be based on the principles of consistency, systematicity, gradualness, repetition, regularity, and individualization. Paediatricians note that the maximum healing effect is provided by cyclic aerobic exercises: walking, light running, cycling and skiing, swimming. They are useful for the respiratory and cardiovascular systems of the child's body. It is important to provide children with a set of daily exercises for flexibility (Sargsyan, 2018).

Rational nutrition is of great importance in the formation of a healthy lifestyle for younger students. It should be based on five basic principles: regularity, adequacy, diversity, safety, and pleasure. At school and at home, children need to be explained that bad habits (smoking, alcohol) have the most severe destructive effect on the child's body. Pupils at the age of 7-10 know or hear about it, but still do not fully realize this information, but may be interested in bad habits, thereby evincing their curiosity (Pavlova, 2017).

In recent years, the problem of the incorrect organization of the time spent by younger students at a computer, smartphone, tablet, and other modern electronic devices has become very urgent, which is extremely dangerous for their health. Minimizing the harmful effects of these devices on the children's body implies compliance with certain rules. In particular, after 30 minutes at the computer, it is important to take a $10-15$-minute break during which simple exercises for the eyes should be performed: focus on the near and far points, move the eyes left and right without turning the head, etc. It is necessary to agree with the child in advance on the time of its work with electronic devices of various types, so that the child is not afraid of restrictions and does not experience negative emotions (Smirnov, 2016).

We shall draw attention to the fact that an important example in the formation of a healthy life for a primary school student is a positive example of teachers and parents, as it is at this age when children have great confidence in adults. Younger students attach serious importance to the words, grades and deeds of teachers and parents. The teacher, by their own example, forms stable ideas about the world and values. All this directly affects the upbringing of a mature personality in children.
The example of an adult in itself contains a personified value. It is important to fill the entire lifestyle of a younger schoolchild with many useful examples of a healthy lifestyle (Popova, 2017).

Healthcare of primary schoolchildren also implies the purposeful formation of their knowledge of a healthy lifestyle. This can be provided in classroom and extracurricular activities. The formation of ideas about healthy lifestyles in children is best done by simple methods and techniques: health lessons, practical exercises, reading, drawing, talking, observing nature, caring for animals and plants, games, and project activities. Especially popular among teachers are «Health Lessons», which they try to conduct on average once a month on topics that children are most interested in («If you want to be healthy», "Sound mind in a sound body», etc.). During such classes, children learn poems, take part in various quizzes, learn the rules of a healthy lifestyle and develop them on their own, complete the corresponding homework independently and together with their parents. All this forms a positive attitude in children and strengthens their motivation for maintaining a healthy lifestyle and following simple rules. Practical exercises most often mean involving parents in the process of educating younger students, since it involves conducting conversations and joint homework, which may be devoted to the most interesting issues for children, including the prevention of bad habits and nature conservation. At the same time, another pedagogical task is being solved - the education of morality, spirituality, mercy, and kindness of children. Within the framework of the «ABC's of health», hygiene, wholesome habits in behaviour, rational nutrition, prevention of overload and fatigue of the body, etc. are instilled in classes with younger students (Popova, 2016)

As part of a healthy lifestyle, literary reading is practiced in schools. In particular, in the lessons teachers introduce children to fragments of works, teach to analyse the behaviour of the main characters, teach them conscious reading, develop literate speech, imagination, attention, forming a negative attitude towards bad habits. In essence, the healthy lifestyle of younger schoolchildren implies everything that helps them to successfully learn, work, have a good rest, solve everyday problems, strengthen their health and be creative. In the educational process of the formation of knowledge about a healthy lifestyle in primary school children, the teacher uses various forms and methods of group and individual work with children. The pedagogical approaches and technologies used at the school will be most effective if teachers and parents instil a desire for a healthy lifestyle in a systematic way and become a role model.

\section{Ways to familiarize children with a healthy lifestyle in the educational process}

The formation of aspirations for a healthy lifestyle in younger schoolchildren implies that the pedagogical process includes the numerous aspects and factors affecting its efficiency. Our study clearly demonstrated that folk pedagogy and ethnopedagogy are useful 
elements of a unified pedagogical system for introducing children to a healthy lifestyle. Nowadays, many Kazakh and foreign scientists (Millan and O’ Daniel, 2017) confirm the fact that a healthy lifestyle is based on many sciences, including biology, ecology, medicine, psychology, pedagogy, ethics, sociology, ethnopsychology, etc. With that, valeology has now received its dynamic development, it shows the laws of the vital functions of the human body, allows to maintain and strengthen one's health, instils personal hygiene skills, provides psychoprophylaxis, indicates the fundamental importance of the development of motor activity.

According to the results of studies on introducing the population to a healthy lifestyle, scientists come to the conclusion that, unfortunately, these issues are most often considered in relation to the adult population. However, they consider it correct to study the current situation specifically with regard to children, especially younger schoolchildren, because it is at that age that the conscious perception of information occurs, habits are formed and the active development of all body systems occurs. Younger students adapt to new conditions and routines, they are curious and listen to the opinions of elders.

Sharing the above positions, another group of scientists (Anisimov, 2017) rightly, in our opinion, indicates that the modern school should pay more attention to providing a personal example of a healthy lifestyle for teachers and parents. They not only solve the problems of improving the health of their children, but also instil in them a sense of ownership in the Kazakh folk culture, special mentality and lifestyle of the country. Children should be proud of their people and understand their contribution to the common cause of introducing the population to a healthy lifestyle. In this regard, authors consider it necessary to supplement the school curricula with the principles, approaches, methods and means of folk pedagogics and ethnopedagogics in the process of upbringing the desire for a healthy lifestyle and its promotion in primary school children.

In this regard, authors believe that there are many scientific works that make it possible to identify Kazakh folk traditions in the pedagogical process and apply them in modern forms and types of educational activities. In particular, it is useful for younger students to organize walking tours of the sights of their native land associated with a healthy lifestyle. It is useful for increasing the motor activity of children, as well as informative and interesting. Authors propose to invite prominent Kazakh thinkers, writers, artists, musicians and scientists who conduct various studies on the healthy lifestyle of children and adults, ways and methods of a fascinating healing of the body, etc.

As part of extracurricular activities, authors consider it useful to conduct environmental workshops in schools where children could engage in project activities, carefully study the world around them, do DIY crafts, take care of birds and animals. All these areas instil in children a sense of beauty, a desire to take care of others, take initiative, create teams and work in them, play useful and entertaining games, move a lot and gradually form the right habits, supplanting curiosity for destructive activities and hobbies. It is important to rely on ethnopedagogics and national pedagogics of the Republic of Kazakhstan in all the events held at the school on healthy lifestyles, which store experience that is useful for the younger generation and development of the country.

\section{Conclusions}

The health of the younger generation is a priority in any family and society at large, it is the youth who will be involved in the socio-economic, political, and cultural development of the state. At primary school age, children consciously begin to form their attitude towards a healthy lifestyle, which is why teachers and parents are called upon to do everything possible to ensure that the younger generation follows it, strengthening physical, mental, and spiritual-moral health. In this difficult task, it is useful for teachers and parents to educate younger students, primarily by personal example, since children are especially susceptible to the words and deeds of adults. At the same time, our study indicated that in the classroom and extracurricular activities in the Republic of Kazakhstan, when forming the desire for a healthy lifestyle in children, it is important to rely on the principles, approaches, methods and means of folk pedagogics and ethnopedagogics. They contain useful experience, folk customs, traditions and values necessary for Kazakhstan's society so as to preserve its national identity in the context of the growing process of globalization and unification of culture.

Teaching a healthy lifestyle to younger schoolchildren in class and during homerooms should take place in a fascinating, informative, modern way. A teacher can turn to popular pedagogics and ethnopedagogics by inviting famous Kazakh writers, poets, artists, musicians or scientists to classes, who have been studying the issues of healthy lifestyles of children and adults for many years and can share their knowledge and personal experience with students. During extracurricular hours, excursions with visits to local attractions can be organized, or an environmental club where children can not only in theory learn the basics of a healthy lifestyle, but also put their knowledge into practice. In particular, they can engage in project activities, make feeders for birds and animals, participate in quizzes and competitions, etc. All this will allow younger students to learn the benefits of a healthy lifestyle and its propaganda by experience, to make health care an interesting and exciting activity. Health is an integral part of human development; it reflects the characteristics of the cultural environment in which a person lives. Thus, the recommendations authors have proposed are of great socio-practical importance for younger students, their parents, teachers, and society at large. Ensuring a competent approach to improving the health of the body of younger schoolchildren allows to develop a high level of awareness of their actions in children, including to acquire useful practical knowledge, skills and abilities that will be useful to them throughout their later life. 


\section{References}

Agafonova, E.V., \& Agafonov, D.V. (2016). The use of health-saving technologies as a means of preserving the health of primary school students. «Formation of a healthy lifestyle for children and adolescents: traditions and innovations»: materials of the international scientific-practical conference (pp. 1318). Belgorod: LLC GiK.

Altynsarin, I. (1976). Collected Works. Vol. 11. Alma-Ata: Nauka.

Anisimov, V.L. (2017). Thoughts on health. Moscow: Physical education and sport.

Aymautov, J. (1999). Folk pedagogics in Kazakhstan. Alma-Ata: Nauka.

Baitursynov, A. (1995). On Kazakh Education. Sound mind in a sound body. In: K.B. Zharikbaev, S.K. Kaliev (Ed.). Anthology of pedagogical thought of Kazakhstan (pp. 228-236). Almaty: Rauan.

Burger, H.G. (2002). Ethno-Pedagogy: A Manual in Cultural Sensitivity, with Techniques for Improving Cross-Cultural Teaching by Fitting Ethnic Patterns. Albuquerque: Southwestern Coop. Educ. Lab., Inc.

Dosmukhamedov, Kh. (1991). Alaman. Almaty: Ana Tili.

Khanbikov, Y.I. (Ed.). (1976). From the history of pedagogy of Tatarstan. Kazan: KSPI.

Komenskiy Ya.A. 2009. Teacher of teachers. Moscow: Karapuz.

Kunanbaev, A. (1977). Complete works in 2 volumes. Volume 1. Alma-Ata: Nauka.

Millan, J., \& O’ Daniel, K. (2017). Healthy lifestyle at school. Harvard Health Publishing, 8, 10-19.

Nigmatov, Z.G. (2017). A pluralistic approach to ethnopedagogical research. Theory and Practice of Physical Education, 8, 20-27.

Pavlova, Yu.V. (2017). Structural and organizational forms of the implementation of extracurricular activities and additional education in the conditions of health-saving and health-forming activities of a general educational institution. In: N.A. Matveeva, E.V. Chetoshnikova (Ed.). Strategy for the formation of a healthy lifestyle for young people: experience and development prospects: materials of an international scientific and practical conference (pp. 56-61). Barnaul: AltGPU.

Petrenko, M.A. (2018). The formation of a healthy lifestyle for younger students. Moscow: Slovo.

Popova, N.V. (2016). Culturological approach as the basis for improving the educational environment of children and youth sports schools. World of Science, Culture, Education, 61(6), 120-127.

Popova, N.V. (2017). The importance of physical education and sports in improving the performance of primary school students in the learning process. In: G.Yu. Lizunov (Ed.). Value orientations of youth in the context of modernization of modern society: a collection of scientific papers (pp. 21-28). GornoAltaysk: Gorno-Altai State University.

Sargsyan, N.A. (2018). Human ecology: health and survival concept. Moscow: PFUR Publishing House.

Smirnov, N.K. (2016). Health-saving educational technologies and the psychology of health at school. Moscow: ARKTI.

Ushinsky, K.D. (1857). About nationality in public education. Journal for Education, 7, 7-19.

Vinogradov, G.S. (1997). Folk pedagogics. Kameny, 1-2, 20-25.

Volkov, G.N. (1974). Ethnopedagogics. Moscow: Academia Publishing Center.

Yarlykova, Î.V. (2015). Formation of the need for a healthy lifestyle within the framework of educational work: a synthesis of the results of applied research. Crimean Scientific Bulletin, 4(2), 281-285.

Yarlykova, Î.V., \& Koryagina, Ye.S. (2016). Forming a healthy lifestyle in younger schoolchildren be means of physical education. Taurida Science Reviewer, 13(6), 89-91.

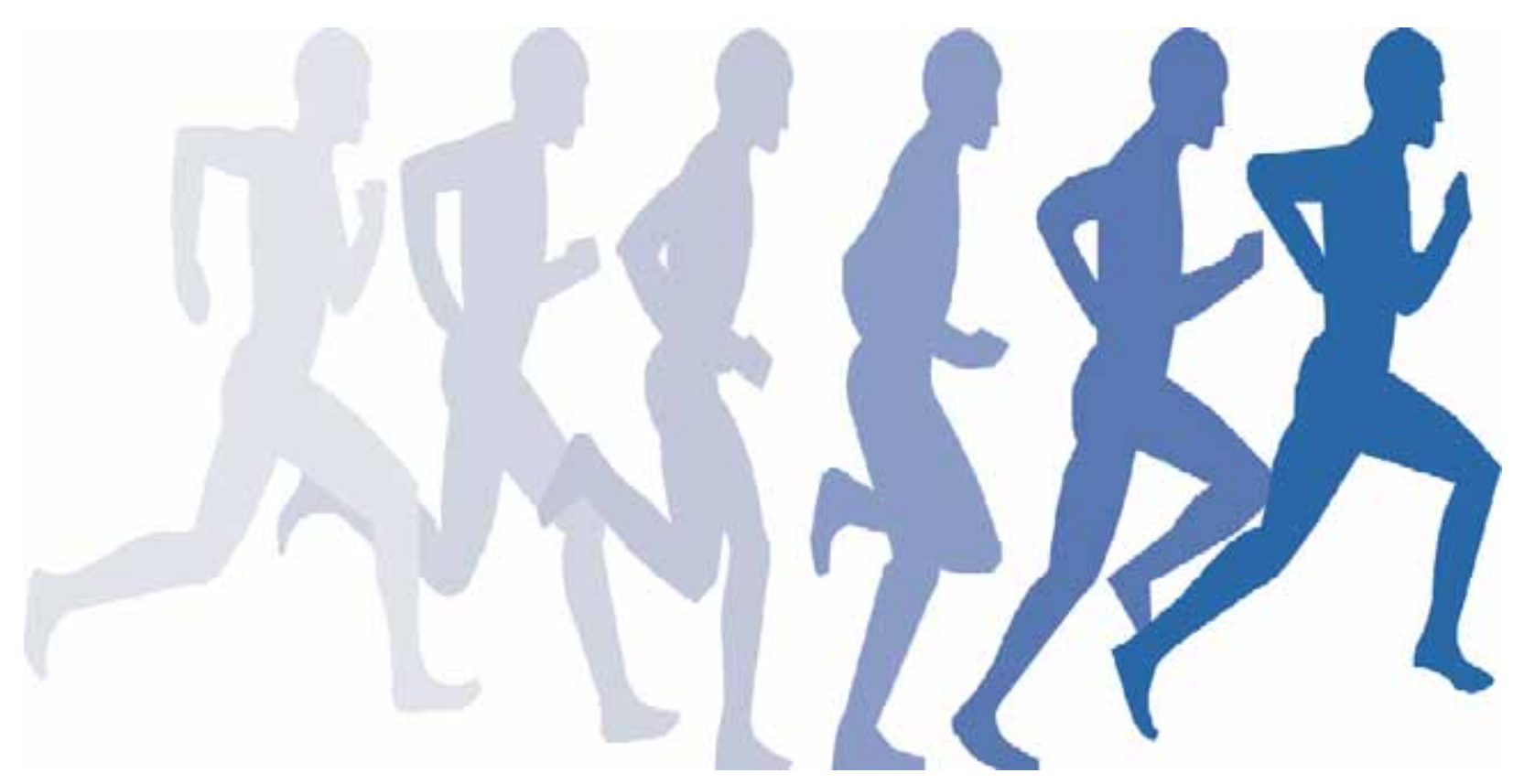

